\title{
Evaluation of dietary effect of cassava peel meal bio-improved with calopogonium mucunoides on nutrient retention and growth performance of broiler chickens \\ ${ }^{* 1}$ Ndelekwute, E. K., ${ }^{2}$ Okereke, C. O., ${ }^{1}$ Assam, E. D. and ${ }^{1}$ Obongekpe, R. \\ ${ }^{\prime}$ Department of Animal Science, University of Uyo, Uyo, Nigeria.

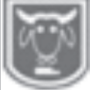 \\ ${ }^{2}$ Livestock Unit, National Root Crops Research Institute, Umudike, Nigeria. \\ *Corresponding author: ndelekwute.ek@gmail.com
}

Abstract

Due to skepticism that follows the use of cassava peel meal, it has been advocated that its nutritive value for poultry be improved. Thus an experiment was conducted to evaluate the dietary effect of cassava peel meal (CPM) improved by supplementing with Calopogonium mucunoides (CM) on apparent nutrient digestibility, growth, meat yield and internal organs of broiler chickens. The CPM was improved by mix-grinding $1000 \mathrm{~g}$ of it with fresh and succulent leaves CM at 0, 10, 20, 30 and 40\% levels, respectively and included in the diets. One hundred and forty-four (144), one day old Hubbard chicks were used. They were grouped into six treatments (T1-T6), replicated into three and with eight birds/replicate in a completely randomized design (CRD). Treatment 1 (T1) was the control diet without CPM, T2 contained unimproved CPM while T3 - T6 contained CPM mixed with 10, 20, 30 and 40\% $C M$, respectively. Feed and water were offered ad libitum for 49 days. Results showed that $C M$ improved the crude protein, ether extract and fibre content of CPM. Live weight and Feed: gain ratio were better $(P<0.05)$ with improved $C P M$ but negatively affected by unimproved CPM at the starter phase. Also at the starter phase feed intake was not altered significantly $(P>0.05)$. At the finisher phase while the live weight was increased by 20-40\% improved CPM, the feed intake was reduced $(P<0.05)$. Best feed: gain ratio was recorded by 40\% improved CM. Unimproved CPM reduced digestibility of dry matter, protein, ether extract and energy utilization; dressed percentage, the weight of breast, gizzard, kidney, pancreas and small intestine but increased bile volume and caeca size. Therefore, it is recommended that 40\% C. muconoides could be used to improve cassava peel meal for inclusion in diets of broiler chickens.

Keywords: apparent nutrient digestibility, broiler chickens, calopogonium mucunoides, cassava peel meal, growth

\section{Une Évaluation de l'effet diététique de la farine d'écorce de manioc bio-améliorée avec le calopogonium mucunoides sur la rétention des nutriments et les performances de croissance des poulets de chair}

\section{Résumé}

A cause du scepticisme qui suit l'utilisation de la farine d'écorce de manioc, il a été préconisé que sa valeur nutritive pour la volaille soit améliorée. Ainsi, une expérience a été menée pour évaluer l'effet diététique de la farine d'écorce de manioc (le 'CPM') améliorée en complétant avec Calopogonium mucunoides (le 'CM') sur la digestibilité apparente des nutriments, la croissance, le rendement en viande et les organes internes des poulets de chair. Le 'CPM' a été amélioré en mélangeant $1000 \mathrm{~g}$ de celui-ci avec des feuilles fraîches et succulentes 'CM'à des niveaux de 0, 10, 20, 30 et 40\% respectivement et inclus dans les régimes. Cent quarantequatre (144) poussins Hubbard d'un jour ont été utilisés. Ils ont été regroupés en six traitements (T1-T6), répliqués en trois et avec huit oiseaux / répliques dans un plan complètement randomisé (le 'CRD'). Le traitement 1 (T1) était le régime témoin sans CPM, 


\section{Effect of bio-improved cassava peel meal on broiler chickens}

T2 contenait du CPMnon amélioré tandis que T3-T6 contenait du CPMmélangé à 10, 20, 30 et $40 \%$ de 'CM', respectivement. Des aliments et de l'eau ont été offerts à volonté pendant 49 jours. Les résultats ont montré que le 'CM'améliorait la teneur en protéines brutes, en extrait d'éther et en fibres $d u$ 'CPM'. Le poids vif et le rapport alimentation : gain étaient meilleurs $(P<0,05)$ avec un 'CPM' amélioré, mais affectés négativement par un 'CPM' non amélioré lors de la phase de démarrage. De même, lors de la phase de démarrage, la prise alimentaire $n^{\prime}$ a pas été modifiée de manière significative $(P>0,05)$. Lors de la phase de finition, alors que le poids vif était augmenté de 20 à $40 \%$ de 'CPM' amélioré, la prise alimentaire était réduite $(P<0,05)$. Le meilleur rapport alimentation : gain a été enregistré par une 'CM' améliorée de 40\%. Le CPM non amélioré réduit la digestibilité de la matière sèche, des protéines, de l'extrait d'éther et de l'utilisation de l'énergie; pourcentage habillé, le poids du sein, du gésier, des reins, du pancréas et de l'intestin grêle mais augmentation du volume de la bile et de la taille des caecas. Par conséquent, il est recommandé d'utiliser $40 \%$ de muconoides de C. pour améliorer la farine de pelure de manioc à inclure dans l'alimentation des poulets de chair.

Mots-clés: digestibilité apparente des nutriments, poulets de chair, calopogonium mucunoides, farine d'écorce de manioc, croissance

\section{Introduction}

Modern feed compounding using various methods and the advent of technology had made it possible to incorporate many ingredients into feed formulation for poultry. Incorporation of many ingredients is an attempt to produce least cost feed whereby farmers could minimize input and maximize profit (Ukachukwu, 1997). In this regard some agricultural and industrial by-products have earlier been recognized (Zafar et al, 2005). Such by-products are palm kernel cake, brewer's dried grains, wheat offal, maize offal, rice bran and cassava peel. However, these industrial byproducts are currently becoming expensive due to high overhead cost associated with their production. Manufacturers now use them to increase their revenue thereby improving their gross margin (Ndelekwute et al., 2020). It is in this realization that farmers and feed manufacturers are changing their operations toward greater reliance on readily available local feedstuffs that are less expensive (Bratte $e t$ al., 2011). Among these products, palm kernel cake, wheat offal and brewer's dried grains are mostly used in poultry feeds in Nigeria compared to cassava peels, a waste product massively produced in Nigeria. Going by reports of Obadina et al. (2006) and Oladunjoye et al. (2010) that cassava peel is $13-20 \%$ of the weight of the fresh cassava tuber, a large volume of it is therefore being produced in Nigeria. According to Karaimu (2015), in Nigeria nearly three million households produce fifty million tons of cassava annually and most of the crop is used for human consumption, but about 14 million tons of its by-products, including peels and undersized tubers are thrown away as waste.

Despite the high volume production of cassava peel, poultry farmers and animal nutritionists have not taken this advantage to reduce cost of production and increase gross margin. This is due to poor nutritional value of cassava peels associated with low energy, low protein and high fibre (Oyebimpe et al., 2006). Nutrient composition of cassava peel is not the only constraint to its use but approximately $98 \%$ of Nigeria's cassava peels annually are wasted due to constraints associated with drying and concerns about safety of use, particularly hydrocyanide and mycotoxinsrelated food poisoning nutrient composition, according to Stapleton 
(2015). To use cassava peel in poultry feeds further processing is required and grinding it to form a meal has been adopted but has not attracted better interest from farmers, feed millers and nutritionists.

Recently Ndelekwute et al. (2020) maintained that cassava peel meal required more value addition to improve its nutritional value and utilization in poultry feeds. They noted that grinding dry cassava peel meal with calopogonium mucunoides improved its protein content and carotenoids, a bioactive compound which cassava peel meal lacks. Ndelekwute et al. (2020) reported that growth performance of broiler chickens was hampered above 20\% when dry cassava peel was substituted weight to weight with different levels (10, 20, 30 and 40\%) of C. mucunoides. The authors observed that above $20 \%$ the metabolizable energy was compromised and suggested further investigation where the different levels of C. mucunoides will be added to a constant weight of dry cassava peel meal.

Therefore, this research was designed to investigate the dietary effect of addition of C. mucunoides to dry cassava peel on growth, carcass yield, internal organs and apparent nutrient digestibility of broiler chickens.

\section{Materials and methods \\ Experimental site}

The experiment was carried out at the Poultry Unit of Teaching and Research Farm of the Department of Animal Science, University of Uyo, Uyo, Akwa Ibom State, Nigeria. The area falls within the tropical rainforest zone of Nigeria. The mean temperature during the experimental period was $32{ }^{\circ} \mathrm{C}$ and humidity $65 \%$ according to University of Uyo Meteorological Station (UUMS, 2020).

Processing and proximate analysis of cassava peel meal

Fresh cassava peels were collected from a garri producing factory thereafter washed and sun dried. Fresh leaves of Calopogonium mucunoides were harvested from fallowed farm land of the Department of Crop Science of the University farm. The leaves were washed with clean water and chopped into pieces with a sharp knife. Different levels of the washed fresh leaves $(100,200,300$ and 400g) were each added to $1000 \mathrm{~g}(1.0 \mathrm{~kg})$ of the dry cassava peel. This represented 10, 20, 30 and $40 \%$ respectively. Each mixture was then ground with grinding machine to pass $2 \mathrm{~mm}$ sieve. The ground material was dried under the sun. After drying it was further ground and sieved to transform the crumbs into small particle sizes to reduce the fibre level (Ndelekwute et al., 2020). Proximate analysis was carried out according to AOAC. (2000) on the C. mucunoides leaves, cassava peel meal and ground mixture of $1000 \mathrm{~g}$ cassava peel $+400 \mathrm{~g} C$. mucunoides.

\section{Experimental design}

One hundred and forty-four (144), one day old Hubbard chicks were used. They were grouped into six treatments (T1-T6), replicated into three and with eight birds/replicate in a completely randomized design (CRD). Treatment 1 (T1) was the control diet without CPM, T2 contained unimproved CPM while T3 - T6 contained CPM mixed with 10, 20, 30 and 40\% CM, respectively. Treatment one was the control diet with no cassava peel meal but contained palm kernel cake, T2 had cassava peel meal without C. mucunoides, T3, T4, T5 and T6 contained cassava peel meal containing $10,20,30$ and $40 \% C$. mucunoides, respectively. The cassava peel meal was included in the diet at the same level (10\%) for starter and 15\% for finisher, as palm kernel cake in the control diet.

$\mathrm{T} 1=$ Control diet without cassava peel meal, but with palm kernel cake.

$\mathrm{T} 2=$ Diet with cassava peel meal without $C$. mucunoides 


\section{Effect of bio-improved cassava peel meal on broiler chickens}

T3 = Diet with cassava peel meal containing $10 \%$ C. mucunoides.

$\mathrm{T} 4=$ Diet with cassava peel meal containing $20 \%$ C. mucunoides.

T5 $=$ Diet with cassava peel meal containing $30 \%$ C. mucunoides.

T6 $=$ Diet with cassava peel meal containing $40 \%$ C. mucunoides.

The statistical model used was:

$$
\begin{aligned}
\mathrm{Y}_{\mathrm{ij}}=\quad & \mu+\mathrm{T}_{\mathrm{i}}+\mathrm{e}_{\mathrm{ij}} \\
& \text { Where: } \\
& \mathrm{Y}_{\mathrm{ij}}=\text { Single observation } \\
& \mu=\text { Overall mean } \\
& \mathrm{T}_{\mathrm{i}}=\text { Treatment effect (value-added- }
\end{aligned}
$$

dry cassava peel meal)

$$
\mathrm{e}_{\mathrm{ij}}=\text { Random error. }
$$

\section{Experimental diets and management of experimental birds}

The management practices adopted by Ndelekwute et al. (2020) were adopted as described. The brooding house and the rearing house were thoroughly swept, washed, disinfected and fumigated. The Floor was covered with wood shavings to serve as bedding material. A day prior to the arrival of the chicks, feeding trays and drinkers were washed with soap and disinfected. On arrival, the day old chicks were randomly assigned to different treatments and their weights noted. The chicks were given glucose via drinking water. Kerosene stove was used to supply heat to provide warmth. The heat was supplied till the third week. On the second day, antibiotics, vitamins and minerals were added to their drinking water for a week. Feed and water were offered ad libitum throughout the experimental period which lasted 49 days.

Conventional feed ingredients were used to formulate the experimental diets (Tables 1 and 2) in line with the recommendation of Olumu (1995) and Oluyemi and Roberts (2000).

Table 1: Composition of experimental starter broiler diets

\begin{tabular}{lllllll}
\hline & \multicolumn{7}{c}{ Levels of Calopogonium mucunoides } & \\
Treatments & $\mathrm{T} 1$ & $\mathrm{~T} 2$ & $\mathrm{~T} 3(10 \%)$ & $\mathrm{T} 4$ & $\mathrm{~T} 5$ & $\mathrm{~T} 6$ \\
Parameters (\%) & $($ Control) & $(0 \%)$ & & $(20 \%)$ & $(30 \%)$ & $(40 \%)$ \\
\hline Maize & 52.0 & 52.0 & 52.0 & 52.0 & 52.0 & 52.0 \\
Soya bean meal & 30.0 & 30.0 & 30.0 & 30.0 & 30.0 & \\
Palm kernel cake & 10.0 & - & - & - & - & - \\
Cassava peel meal (CPM) & - & 10.0 & - & - & - & - \\
Value added CPM & - & - & 10.0 & 10.0 & 10.0 & 10.0 \\
Fish meal & 4.0 & 4.0 & 4.0 & 4.0 & 4.0 & 4.0 \\
Bone meal & 3.0 & 3.0 & 3.0 & 3.0 & 3.0 & 3.0 \\
Salt & 0.25 & 0.25 & 0.25 & 0.25 & 0.25 & 0.25 \\
Lysine & 0.20 & 0.20 & 0.20 & 0.20 & 0.20 & 0.20 \\
Methionine & 0.20 & 0.20 & 0.20 & 0.20 & 0.20 & 0.20 \\
Premix* & 0.35 & 0.35 & 0.35 & 0.35 & 0.35 & 0.35 \\
\hline Total & $\mathbf{1 0 0}$ & $\mathbf{1 0 0}$ & $\mathbf{1 0 0}$ & $\mathbf{1 0 0}$ & $\mathbf{1 0 0}$ & $\mathbf{1 0 0}$ \\
& & & & & & \\
Nutrient Composition $(\%)$ & & & & & & 22.45 \\
\hline Crude protein & 22.88 & 21.18 & 21.30 & 21.38 & 22.46 & 22.54 \\
Ether extract & 4.70 & 4.61 & 4.68 & 4.67 & 4.65 & 4.65 \\
Crude fibre & 4.80 & 4.95 & 4.95 & 4.95 & 4.86 & 4.40 \\
Ash & 6.53 & 6.52 & 6.53 & 6.53 & 6.53 & 6.64 \\
Lysine & 1.20 & 1.15 & 1.15 & 1.15 & 1.15 & 1.16 \\
Methionine & 0.34 & 0.34 & 0.34 & 0.34 & 0.34 & 0.35 \\
Calcium & 1.23 & 1.23 & 1.23 & 1.23 & 1.23 & 1.23 \\
Phosphorus & 0.85 & 0.80 & 0.80 & 0.80 & 0.81 & 0.81 \\
Energy KcalME/kg & 2890 & 2850 & 2850 & 2835 & 2835 & 2830 \\
\hline
\end{tabular}

* $1 \mathrm{~kg}$ of premix contains: Vitamin A $(10,000,000 \mathrm{iu})$, vitamin $\mathrm{E}(16,000 \mathrm{mg})$, vitamin $\mathrm{k} 3$ (800mg), vitamins $\mathrm{B}_{12}$ (22,000mg), niacin (22,000mg), vitamin $\mathrm{B}_{2}(10 \mathrm{mg})$, folic acid (400mg), biotin (32mg), chlorine chloride $(200,000 \mathrm{mg})$ zinc $(32,000 \mathrm{mg})$, iodine $(600 \mathrm{mg})$, cobalt $(120 \mathrm{mg})$, selenium $(40 \mathrm{mg})$, antioxidant (48,000mg) 
Ndelekwute, Okereke, Assam and Obongekpe

Table 2: Composition of experimental finisher broiler diets

\begin{tabular}{lllllll}
\hline \multicolumn{7}{c}{ Levels of Calopogonium mucunoides } \\
Treatments & $\mathrm{T} 1$ & $\mathrm{~T} 2(0 \%)$ & $\mathrm{T} 3$ & $\mathrm{~T} 4$ & $\mathrm{~T} 5$ & $\mathrm{~T} 6$ \\
Parameters (\%) & (Control) & & $(10 \%)$ & $(20 \%)$ & $(30 \%)$ & $(40 \%)$ \\
\hline Maize & 52.00 & 52.00 & 52.00 & 52.00 & 52.0 & 52.0 \\
Soya bean meal & 28.0 & 28.00 & 28.0 & 28.0 & 28.0 & 28.0 \\
Palm kernel cake & 15.0 & - & - & - & - & - \\
Cassava peel meal (CPM) & - & 15.0 & - & - & - & - \\
Value added CPM & - & - & 15.0 & 15.0 & 15.0 & 15.0 \\
Fish meal & 2.0 & 2.0 & 2.0 & 2.0 & 2.0 & 2.0 \\
Bone meal & 3.0 & 3.0 & 3.0 & 3.0 & 3.0 & 3.0 \\
Salt & 0.25 & 0.25 & 0.25 & 0.25 & 0.25 & 0.25 \\
Lysine & 0.10 & 0.10 & 0.10 & 0.10 & 0.10 & 0.10 \\
Methionine & 0.10 & 0.10 & 0.10 & 0.10 & 0.10 & 0.10 \\
Premix* & 0.25 & 0.25 & 0.25 & 0.25 & 0.25 & 0.25 \\
\hline Total & $\mathbf{1 0 0}$ & $\mathbf{1 0 0}$ & $\mathbf{1 0 0}$ & $\mathbf{1 0 0}$ & $\mathbf{1 0 0}$ & $\mathbf{1 0 0}$ \\
Nutrient composition (\%) & & & & & & \\
Crude protein & 20.23 & 19.15 & 19.45 & 19.70 & 20.05 & 20.40 \\
Crude Fibre & 6.75 & 7.02 & 6.59 & 6.58 & 6.34 & 6.21 \\
Ether Extract & 4.78 & 4.01 & 4.01 & 4.05 & 4.05 & 4.07 \\
Ash & 5.43 & 5.47 & 5.47 & 5.48 & 5.47 & 5.49 \\
Lysine & 1.00 & 1.00 & 1.00 & 1.00 & 1.00 & 1.00 \\
Methionine & 0.32 & 0.32 & 0.32 & 0.32 & 0.32 & 0.32 \\
Calcium & 1.01 & 1.01 & 1.01 & 1.01 & 1.01 & 1.01 \\
Phosphorus & 0.80 & 0.80 & 0.80 & 0.80 & 0.80 & 0.80 \\
Energy KcalME/kg & 2930 & 2875 & 2875 & 2866 & 2861 & 2862 \\
\hline
\end{tabular}

*1 kg premix contained: vitamin A (10,000,000iu), vitamin D3 (1,000,000iu), vitamin E (16,000 $\mathrm{mg})$, vitamin k3 (800mg), vitamins $B_{2}(22,00 \mathrm{mg})$, niacin $(22,00 \mathrm{mg})$, vitamin B ${ }_{12}(10 \mathrm{mg})$, Folic Acid (400mg) Biotin (32mg), Chlorine chloride (200,00mg), Zinc (32,000mg) iodine (600mg), cobalt (12mg), selenium (40mg), antioxidant $(48,000 \mathrm{mg})$.

\section{Data collection and analysis}

This was followed as described by Ndelekwute et al. (2020). The live body weight was obtained weekly using a $20 \mathrm{~kg}$ capacity Camry weighing scale. The weight gain was calculated by subtracting the initial weight from the final weight. The feed intake of each replicate was calculated by subtracting the quantity of the leftover feed from the quantity of feed fed the previous day. This was later divided by the number of birds in the replicate, to give the average feed intake per bird. The feed: gain ratio, protein intake and protein efficiency ratio were also calculated.

Feed: gain ratio $=$ daily feed intake $(\mathrm{g})$ daily weight gain $(\mathrm{g})$

Protein intake was calculated by multiplying the percentage crude protein
(CP) in the feed by the daily feed intake.

Daily protein intake $(\mathrm{DPI})=\% \mathrm{CP}$ in feed $\times$ daily feed intake.

The protein efficiency ratio (PER) was calculated based on the daily weight gain and daily protein intake. $\mathrm{PER}=\underline{\text { daily weight }}$ gain $(\mathrm{g})$

$$
\text { daily protein intake }(\mathrm{g})
$$

\section{Digestibility studies}

This involved adoption of total collection method. Metabolism cages used were thoroughly washed and disinfected. At the end of the feeding experiment, one bird from each of the three replicates of a dietary group giving a total of 18 birds were randomly assigned to a metabolism cage each. Male birds were used and the birds had similar weight. This was to reduce the effect of sex and weight on digestibility. The birds were acclimatized for four days and 


\section{Effect of bio-improved cassava peel meal on broiler chickens}

fed their individual experimental diets. At the end of the acclimatization period, feed intake was recorded and faecal samples were collected for four days. To minimize feed wastages, feeding was done in the morning by 8.00 hours GMT, in the afternoon by 1.00 hours and in the evening by 6.00 hours making sure the birds did not lack feed at any point in time (Ndelekwute et al., 2020). Collected faecal samples were immediately taken to the laboratory where they were oven dried at $60^{\circ} \mathrm{C}$ to constant weight. Dry faecal samples were ground to pass through $1 \mathrm{~mm}$ sieve. The four days faecal samples were pooled and thoroughly mixed. A sample was taken from each treatment, stored in a refrigerator from which proximate analysis was carried out according to AOAC. (2000).

\section{Carcass and internal organs analyses}

At the end of the feeding experiment, 18 birds one from each replicate of a treatment were used for carcass analysis. The birds were fasted for 18 hours. They were slaughtered by severing the throat with a sharp knife after recording their weight. The slaughtered birds were immersed in $60^{\circ} \mathrm{C}$ hot water for 30 seconds according to Scott et al. (1969) as reported by Ndelekwute et al. (2018). The feathers were plucked by hand. Carcass processing was done by cutting the legs, head and the neck and the crop gently removed. The abdomen was cut open and the viscera pulled out.

The abdominal fat was removed. The different carcass parts (breast, thigh, drumstick, wing and back) were cut and separated. Weights of the carcass parts and abdominal fat were noted. Dressed carcass weight, internal organs and abdominal fat were expressed as percentage live weight
(Abaza et al., 2008), while cut-parts were expressed as percentage dressed weight as reported by Ndelekwute et al. (2018).

\section{Data analysis}

Data collected were subjected to Analysis of Variance (ANOVA). Significant means were compared using Duncan's Multiple Range Test (Steel and Torrie; 1980).

\section{Results and discussion \\ Proximate result}

The proximate result of cassava peel meal, C. mucunoides and ground mixture of $40 \%$ C. mucunoides and dry cassava peel is shown in Table 3. Calopogonium mucunoides had higher crude protein and lower crude fibre than the cassava peel meal. Crude protein and ether extract of $C$. mucunoides were similar to $24.65 \%$ and $3.11 \%$ respectively reported by Obua et al. (2014). However, Obua et al. (2014) reported higher crude fibre $(21.69 \%)$ and ash $(9.79 \%)$ probably due to soil type, stage of growth and season of the year (Obua et al., 2014). Crude protein, crude fibre and ash levels of the cassava peel meal were at variance with $4.20,12.70$ and $8.70 \%$ respectively reported by Dayal et al. (2018). The ether extract of present report was in consonance with Dayal et al. (2018). Babatunde (2013) reported crude protein of cassava peel meal to be 3.10 , crude fibre 9.40 and ash $9.80 \%$. Variation could be due to processing (peeling) method adopted by cassava processing factories. The proximate result of ground mixture of $C$. mucunoides and cassava peel showed that C. mucunoides improved the crude protein, ether extract and crude fibre of the cassava peel meal. The crude protein was improved from $3.56-10.43 \%$ and fibre 22.65 $18.65 \%$.

Table 3: Proximate composition (\%) of cassava peel meal and $C$. mucunoides

\begin{tabular}{llll}
\hline Parameters & CPM & C. mucunoides & Mixture \\
\hline Crude protein & 3.56 & 23.88 & 10.43 \\
Ether extract & 1.21 & 3.01 & 2.17 \\
Crude fibre & 22.65 & 11.01 & 18.65 \\
Ash & 6.02 & 5.85 & 5.75 \\
\hline CPM = Cassava peel meal, mixture $=$ & 1000g CPM $+400 \mathrm{~g} \mathrm{C.} \mathrm{mucunoides}$ \\
\multicolumn{4}{c}{$\mathbf{9 6}$}
\end{tabular}




\section{Ndelekwute, Okereke, Assam and Obongekpe}

Effect of improved cassava peel meal on growth performance of broiler chickens

Table 4 indicates the effect of improved cassava peel meal on growth performance of starter broilers. Final live weight, daily gain, feed: gain ratio and daily protein intake were significantly $(\mathrm{P}<0.05)$ affected, while feed intake and protein efficiency ratio were not significantly affected
$(\mathrm{P}>0.05)$. Unimproved cassava peel meal had negative impact on the final live weight, daily gain and feed; gain ratio. There were no significant differences $(\mathrm{P}>0.05)$ between control and all the cassava peel meal improved by different levels of $C$. mucunoides for the indices mentioned. It was observed that control consumed more protein than any of the other treatments.

Table 4: Effect of bio-improved cassava peel meal on performance of starter broiler chicks

\begin{tabular}{llllllll}
\hline & \multicolumn{7}{c}{ Levels of Calopogonium mucunoides } \\
\cline { 2 - 6 } & T1 & $\mathrm{T} 2$ & $\mathrm{~T} 3$ & $\mathrm{~T} 4$ & $\mathrm{~T} 5$ & $\mathrm{~T} 6$ & \\
Parameters & $($ Control) & $(0 \%)$ & $(10 \%)$ & $(20 \%)$ & $(30 \%)$ & $(40 \%)$ & SEM \\
\hline Initial live weight (g/bird) & 42.0 & 41.0 & 41.0 & 42.0 & 41.0 & 42.0 & 4.05 \\
Final live weight (g/bird) & $1075^{\mathrm{a}}$ & $981^{\mathrm{b}}$ & $1050^{\mathrm{a}}$ & $1047^{\mathrm{a}}$ & $1055^{\mathrm{a}}$ & $1062^{\mathrm{a}}$ & 58.87 \\
Daily weight gain (g/bird) & $36.89^{\mathrm{a}}$ & $33.57^{\mathrm{b}}$ & $36.04^{\mathrm{a}}$ & $35.89^{\mathrm{a}}$ & $36.21^{\mathrm{a}}$ & $36.43^{\mathrm{a}}$ & 2.32 \\
Total feed intake (g/bird) & 1647 & 1609 & 1645 & 1608 & 1585 & 1588 & 76.54 \\
Daily feed intake (g/bird) & 58.82 & 57.46 & 58.75 & 57.43 & 56.61 & 56.71 & 5.08 \\
Feed: gain ratio & $1.59^{\mathrm{b}}$ & $1.70^{\mathrm{a}}$ & $1.63^{\mathrm{b}}$ & $1.60^{\mathrm{b}}$ & $1.56^{\mathrm{b}}$ & $1.56^{\mathrm{b}}$ & 0.07 \\
Daily protein intake (g/bird) & $13.34^{\mathrm{a}}$ & $12.17^{\mathrm{b}}$ & $12.51^{\mathrm{b}}$ & $12.46^{\mathrm{b}}$ & $12.48^{\mathrm{b}}$ & $12.67^{\mathrm{b}}$ & 0.90 \\
Protein efficiency ratio & $2.77^{\mathrm{b}}$ & $2.76^{\mathrm{b}}$ & $2.88^{\mathrm{b}}$ & $2.86^{\mathrm{b}}$ & $2.90^{\mathrm{b}}$ & $2.88^{\mathrm{b}}$ & 0.09 \\
\hline
\end{tabular}

abc. means along the same row with different superscripts are significantly $(\mathrm{P}<0.05)$ different.

The effect of improved cassava peel on broiler chickens at the finisher phase is shown in Table 5. At this phase trend of events changed. The final live weight of unimproved cassava peel meal improved significantly $(\mathrm{P}<0.05)$ being similar to that of $10 \%$. Above $10 \%$ improved cassava peel meal yieded similar final live weight as the control. Similarly, above $10 \%$ total feed intake was significantly $(\mathrm{P}<0.05)$ reduced. There was no significant difference $(\mathrm{P}>0.05)$ in total feed intake of control, unimproved and $10 \%$. Feed: gain ratio was better in $40 \%$ compared to unimproved, $10 \%$ and control, but similar to 20 and $30 \%$. The same parameter was similar in control and unimproved meal which concurred with Dayal et al. (2018). Inclusion of improved cassava peel meal did not significantly $(\mathrm{P}>0.05)$ influence daily gain, daily feed intake, daily protein intake and protein efficiency ratio. The reduced live weight and similarity in feed intake at starter phase of unimproved meal compared to control was consistent with Babatunde (2013) and Dayal et al. (2018). However, similarity in feed intake was at variance with Odunsi et al. (2001) who observed linear decrease in feed intake as level of cassava peel meal was increased. Though unimproved meal gave similar daily protein as improved meal, the feed: gain ratio was poor, suggesting its poor quality.

The improvement recorded by unimproved meal in live weight, compared to $10 \%$, and total feed intake and feed: gain ratio compared to control and $10 \%$ at the finisher phase, shows that cassava peel meal could be better utilized at finisher phase of production. This could be as a result of adaptation and age factor when the birds were physiologically mature to handle cassava peel meal. The poor live weight exhibited by birds that consumed unimproved cassava peel meal was in line with the reports of Odunsi et al. (2001) and Babatunde (2013). 
Table 5: Effect of bio-improved cassava peel meal on performance of finisher broiler Chickens

\begin{tabular}{|c|c|c|c|c|c|c|c|}
\hline \multicolumn{8}{|c|}{ Levels of Calopogonium mucunoides } \\
\hline $\begin{array}{l}\text { Treatments } \\
\text { Parameters }\end{array}$ & $\begin{array}{l}\mathrm{T} 1 \\
\text { (Control) }\end{array}$ & $\begin{array}{l}\mathrm{T} 2 \\
(0 \%)\end{array}$ & $\begin{array}{l}\text { T3 } \\
(10 \%)\end{array}$ & T4 (20\%) & $\begin{array}{l}\text { T5 } \\
(30 \%)\end{array}$ & $\begin{array}{l}\text { T6 } \\
(40 \%)\end{array}$ & SEM \\
\hline Initial live weight (g/bird) & $1075^{\mathrm{a}}$ & $981^{b}$ & $1050^{\mathrm{a}}$ & $1047^{\mathrm{a}}$ & $1055^{\mathrm{a}}$ & $1062^{\mathrm{a}}$ & 58.87 \\
\hline Final live weight ( $\mathrm{g} / \mathrm{bird}$ ) & $2005^{\mathrm{a}}$ & $1880^{\circ}$ & $1903^{\mathrm{bc}}$ & $1953^{\mathrm{ab}}$ & $1950^{\mathrm{ab}}$ & $2001^{\mathrm{a}}$ & 85.09 \\
\hline Daily weight gain (g/bird) & 44.29 & 42.81 & 40.62 & 43.14 & 42.62 & 44.71 & 4.45 \\
\hline Total feed intake (g/bird) & $2942^{\mathrm{a}}$ & $2933^{\mathrm{a}}$ & $2950^{\mathrm{a}}$ & $2818^{b}$ & $2813^{\mathrm{b}}$ & $2824^{\mathrm{b}}$ & 110 \\
\hline Daily feed intake ( $\mathrm{g} / \mathrm{bird})$ & 140.0 & 140.0 & 141.0 & 134.0 & 134.0 & 135.0 & 21.05 \\
\hline Feed: gain ratio & $3.16^{\mathrm{ab}}$ & $3.27^{\mathrm{a}}$ & $3.23^{\mathrm{a}}$ & $3.11^{\mathrm{bc}}$ & $3.14^{\mathrm{bc}}$ & $3.01^{\mathrm{c}}$ & 0.14 \\
\hline Daily protein intake $(\mathrm{g} / \mathrm{bird})$ & 28.32 & 26.81 & 27.42 & 26.40 & 26.87 & 27.54 & 2.14 \\
\hline Protein efficiency ratio & $1.56^{\mathrm{a}}$ & $1.80^{\mathrm{a}}$ & $1.47^{\mathrm{b}}$ & $1.64^{\mathrm{b}}$ & $1.57^{\mathrm{b}}$ & $1.62^{\mathrm{b}}$ & 0.19 \\
\hline
\end{tabular}

abc. means along the same row with different superscripts are significantly $(\mathrm{P}<0.05)$ different.

This present result shows the nutritional importance of C. mucunoides and it aligned with the previous advocacy for improvement of the nutritive value of cassava peel meal for better performance of poultry (Ndelekwute et al., 2020). The performance of improved cassava peel meal over unimproved could be linked to the higher crude protein and lower fibre content of the improved cassava peel meal (Table 1). Also, as a source of carotenoids the presence of C. mucunoides could have resulted to better health and immunity and subsequently better productivity. A critical observation was made when comparing this result with Ndelekwute et al. (2020). By weight to weight substitution of cassava peel meal for C. mucunoides at 0, 10, 20, 30 and $40 \%$ as means of enriching cassava peel meal, Ndelekwute et al. (2020) reported that final live weight and feed intake of broiler chickens were negatively $(\mathrm{P}<0.05)$ affected at 30 and $40 \%$ of C. mucunoides compared to control. This is at variance with the present report where the cassava peel was supplemented rather than substituted with C. mucunoides. They reported that by weight to weight substitution, the energy of the cassava peel meal was compromised and suggested nonsubstitution approach which was adopted in this present work which could have paid off. Effect of improved cassava peel meal on apparent nutrient digestibility of broilers
The apparent nutrient digestibility as affected by different diets is indicated in Table 6. All the indices were significantly $(\mathrm{P}<0.05)$ affected by diets except crude fibre and ash. While unimproved cassava peel meal negatively affected digestibility of dry matter, protein and energy utilization, 20,30 and $40 \%$ improved them. However, the digestibility of dry matter, protein and energy utilization were similar in control, 20, 30 and $40 \%$. Further observation showed that both improved and unimproved cassava peel meal reduced ether extract digestibility. This poor digestibility could have accounted for the poor growth performance of unimproved meal. Digestibility has positive relationship with live weight or growth (MacDonald et al., 2000).

These results agreed with Aguihe et al. (2015) who observed that digestibility of birds fed cassava peel meal based diet deteriorated and only improved when enzyme was supplemented. It also concurred with Odunsi et al. (2001), Babatunde (2013) and Dayal et al. (2018).

Effect of improved cassava peel meal on meat yield of broilers

Table 7 is showing the effect of improved cassava peel meal on meat of the chickens. Dressed percentage, breast weight and back-cut were affected significantly $(\mathrm{P}<0.05)$. Thigh weight, drumstick and wing were not significantly affected 
$(\mathrm{P}>0.05)$. Birds that consumed unimproved cassava peel meal and 10\% Calopogonium mucunoides improved meal had lower dressed percentage compared to control, 20, 30 and $40 \%$. Further observation showed that the dressed percentage of control, 20, 30 and $40 \%$ were equal
$(\mathrm{P}>0.05)$. Back-cut in unimproved and $10 \%$ groups were equal but lower compared to control, 20, 30 and 40\% which were also similar. The results of carcass yield, breast, thigh and drumstick between control and unimproved meal were consistent with the report of Dayal et al. (2018).

Table 6: Effect of bio-improved cassava peel meal on apparent nutrient digestibility broiler Chickens

\begin{tabular}{llllllll}
\hline & \multicolumn{9}{c}{ Levels of Calopogonium mucunoides } & & \\
Treatments & T1 & T2 & T3 (10\%) & T4 & T5 (30\%) & T6 (40\%) & SEM \\
Parameters & (Control) & $(0 \%)$ & & $(20 \%)$ & & & \\
\hline Dry matter (\%) & $72.49^{\mathrm{a}}$ & $62.12^{\mathrm{b}}$ & $62.34^{\mathrm{b}}$ & $65.05^{\mathrm{b}}$ & $70.08^{\mathrm{a}}$ & $70.67^{\mathrm{a}}$ & 5.76 \\
Crude protein (\%) & $68.05^{\mathrm{a}}$ & $62.00^{\mathrm{b}}$ & $63.11^{\mathrm{b}}$ & $65.08^{\mathrm{ab}}$ & $67.89^{\mathrm{a}}$ & $67.56^{\mathrm{a}}$ & 4.89 \\
Ether extract (\%) & $88.66^{\mathrm{a}}$ & $75.00^{\mathrm{b}}$ & $74.87^{\mathrm{b}}$ & $85.08^{\mathrm{b}}$ & $84.88^{\mathrm{b}}$ & $85.99^{\mathrm{b}}$ & 6.65 \\
Crude fibre (\%) & 42.09 & 40.0 & 41.67 & 41.0 & 40.56 & 40.50 & 3.76 \\
Ash (\%) & 62.77 & 63.08 & 61.89 & 64.01 & 63.75 & 62.88 & 4.09 \\
Energy utilization (\%) & $78.76^{\mathrm{a}}$ & $61.34^{\mathrm{c}}$ & $62.08^{\mathrm{c}}$ & $72.12^{\mathrm{b}}$ & $77.89^{\mathrm{a}}$ & $77.90^{\mathrm{a}}$ & 7.32 \\
\hline
\end{tabular}

abc. means along the same row with different superscripts are significantly $(\mathrm{P}<0.05)$ different

Table 7: Effect of bio-improved cassava peel meal on carcass yield of broiler chickens

\begin{tabular}{llllllll}
\hline & \multicolumn{7}{c}{ Levels of Calopogonium mucunoides } \\
$\begin{array}{l}\text { Treatments } \\
\text { Parameters }\end{array}$ & T1 & T2 (0\%) & T3 $(10 \%)$ & T4 $(20 \%)$ & T5 & T6 (40\%) & SEM \\
\hline Dressed (\%) & $71.33^{\mathrm{a}}$ & $62.00^{\mathrm{b}}$ & $63.11^{\mathrm{b}}$ & $68.14^{\mathrm{a}}$ & $68.04^{\mathrm{a}}$ & $69.01^{\mathrm{a}}$ & 7.63 \\
Breast weight (\%) & $38.56^{\mathrm{a}}$ & $32.25^{\mathrm{c}}$ & $31.95^{\mathrm{c}}$ & $36.88^{\mathrm{a}}$ & $41.79^{\mathrm{a}}$ & $40.90^{\mathrm{a}}$ & 3.76 \\
Thigh weight (\%) & 16.08 & 15.28 & 16.09 & 16.50 & 16.65 & 16.51 & 2.76 \\
Drumstick (\%) & 13.17 & 12.98 & 13.26 & 13.05 & 13.10 & 12.06 & 1.88 \\
Back-cut (\%) & $22.13^{\mathrm{b}}$ & $25.68^{\mathrm{a}}$ & $25.33^{\mathrm{a}}$ & $22.11^{\mathrm{b}}$ & $22.00^{\mathrm{b}}$ & $21.88^{\mathrm{b}}$ & 2.89 \\
Wing (\%) & 11.43 & 11.66 & 10.67 & 11.80 & 12.08 & 12.34 & 1.96 \\
\hline
\end{tabular}

abc. means along the same row with different superscripts are significantly $(\mathrm{P}<0.05)$ different.

Effect of improved cassava peel meal on internal organs of broilers

Improved cassava peel meal showed significant $(\mathrm{P}<0.05 \%)$ effect on all the parameters except proventriculus, heart, liver and spleen (Table 8). Bigger and similar gizzard sizes were observed in control and above 10\% improvement compared to unimproved and $10 \%$ which were also the same. Large size of gizzard has economic importance as its demand is high. Also large gizzard is good for better grinding of ingested feed. Unimproved cassava peel meal shrink kidney and small intestine significantly $(\mathrm{P}<0.05)$. Shrinking of kidney and small intestine could lead to reduced kidney function and nutrient processing by small intestine.

All levels of improved meal including the control produced similar weight of kidney and small intestine. Both improved and unimproved cassava peel meal inflamed caeca. Large size of caeca could be as a result of undigested cassava peel meal and C. mucunoides forming a substrate for microbial growth and fermentation. The results of liver, pancreas, proventriculus, small intestine and caeca were in agreement with Dayal et al. (2018). 


\section{Effect of bio-improved cassava peel meal on broiler chickens}

Table 8: Effect of bio-improved cassava peel meal on internal organs of broiler chickens

\begin{tabular}{|c|c|c|c|c|c|c|c|}
\hline \multirow{3}{*}{$\begin{array}{l}\text { Treatments } \\
\text { Parameters }\end{array}$} & \multicolumn{6}{|c|}{ Levels of Calopogonium mucunoides } & \multirow{3}{*}{ SEM } \\
\hline & $\mathrm{T} 1$ & $\mathrm{~T} 2(0 \%)$ & $\mathrm{T} 3(10 \%)$ & T4 $(20 \%)$ & T5 & T6 & \\
\hline & (Control) & & & & $(30 \%)$ & $(40 \%)$ & \\
\hline Proventriculus (\%) & 1.82 & 1.88 & 1.91 & 1.87 & 2.00 & 1.87 & 0.26 \\
\hline Gizzard (\%) & $1.91^{\mathrm{a}}$ & $1.59^{\mathrm{b}}$ & $1.72^{\mathrm{b}}$ & $2.19^{\mathrm{a}}$ & $2.21^{\mathrm{a}}$ & $2.31^{\mathrm{a}}$ & 0.31 \\
\hline Liver $(\%)$ & 2.88 & 2.74 & 2.89 & 2.96 & 2.79 & 2.75 & 0.31 \\
\hline Heart $(\%)$ & $0.44^{\mathrm{b}}$ & $0.51^{\mathrm{a}}$ & $0.57^{\mathrm{a}}$ & $0.58^{\mathrm{a}}$ & $0.56^{\mathrm{a}}$ & $0.45^{\mathrm{b}}$ & 0.06 \\
\hline Kidney $(\%)$ & $0.47^{\mathrm{a}}$ & $0.32^{\mathrm{c}}$ & $0.38^{\mathrm{b}}$ & $0.40^{\mathrm{b}}$ & $0.41^{b}$ & $0.41^{b}$ & 0.05 \\
\hline Pancreas $(\%)$ & $0.36^{\mathrm{a}}$ & $0.29^{b}$ & $0.40^{\mathrm{a}}$ & $0.40^{\mathrm{a}}$ & $0.39^{\mathrm{a}}$ & $0.40^{\mathrm{a}}$ & 0.06 \\
\hline Spleen $(\%)$ & $0.30^{\mathrm{a}}$ & $0.17^{b}$ & $0.20^{\mathrm{b}}$ & $0.21^{\mathrm{b}}$ & $0.21^{b}$ & $0.20^{\mathrm{b}}$ & 0.02 \\
\hline Bile volume (\%) & $0.05^{b}$ & $0.07^{\mathrm{a}}$ & $0.08^{\mathrm{a}}$ & $0.04^{b}$ & $0.05^{\mathrm{b}}$ & $0.05^{b}$ & 0.002 \\
\hline Small intestine $(\%)$ & $4.80^{\mathrm{a}}$ & $3.35^{\mathrm{b}}$ & $4.50^{\mathrm{a}}$ & $4.40^{\mathrm{a}}$ & $4.45^{\mathrm{a}}$ & $4.54^{\mathrm{a}}$ & 1.01 \\
\hline Caeca $(\%)$ & $0.40^{\mathrm{b}}$ & $0.43^{b}$ & $0.45^{\mathrm{b}}$ & $0.66^{\mathrm{a}}$ & $0.65^{\mathrm{a}}$ & $0.65^{\mathrm{a}}$ & 0.20 \\
\hline
\end{tabular}

abc. means along the same row with different superscripts are significantly $(\mathrm{P}<0.05)$ different.

\section{Conclusion}

The results reported in this work clearly indicated that cassava peel meal as a potential agricultural waste could be improved nutritionally. Calopogonium mucunoides as a source of folia protein and carotenoids had proved in this report to be essential bio-organic material for this purpose. While unimproved cassava peel meal had negative effects on the growth performance, apparent nutrient digestibility, meat yield, kidney and pancreas, they were improved by feeding cassava peel meal improved by $C$. mucunoides up to $40 \%$. Hence farmers, feed millers and animal nutritionists could incorporate cassava peel meal improved by $40 \%$ C. mucunoides into diets for broilers.

\section{References}

Abaza, M. I., Shehata, M. A., Shoieb, M. S. and Hassan, I. I. 2008. Evaluation of some natural feed additives in growing chick diets. International Journal of Poultry Science, 7(9): 872 - 879.

Aguihe, P. C., Kehinde, A. S, Babatunde, T. O. and Iyayi, E. A. 2015. Effect of supplementation of cassava peel meal based diet with enzyme Maxigrain ${ }^{\circledR}$ on performance, apparent nutrient digestibility and economic indices of broiler finishers. Nigerian Journal of Animal Production, 42(1):

AOAC. 2000. Official Methods of Analysis. 15th edition. Washington D.C., USA (2000).

Babatunde, B. B. 2013. Effect of Feeding Cassava Wastes on the Performance and Meat Quality of Broiler Chickens. Malasian Journal of Animal Science, 16(2): 63-73.

Bratte, L., Amata, I. A., Omeje, S. I. and Egbunike, G. N. 2011. The effects of partial replacement of dietary maize with seeds of the African pear (Dacryode edulis) on semen characteristics of broiler breeder cocks. Asian Journal of Animal Science, 5:71-79.

Dayal, A. D., Diarra, S. S, Lameta, S., Devi, A. and Amosa, F. 2018. High cassava peel meal-based diets with animal fat and enzyme for broilers. Livestock Research for Rural Development.

Karaimu, P. 2015. From food waste to animal feed, cassava peels potentially big business for $\begin{array}{llllllll} & \mathbf{i} & \mathbf{g} & \mathbf{e} & \mathbf{r} & \mathbf{i} & \mathbf{a} & \mathbf{n}\end{array}$ women.www.news.ilri.org/2015/0 7/09/from-food-waste-to-animalfeed-cassava-peels-potentiallybig-business-for-nigerian-women/ 
MacDonald, P., Edwards, R. A. and Greenhalgh, J. F. D. 2000. Animal Nutrition. $5^{\text {th }}$ ed. Longman, London.

Ndelekwute, E. K, Enyenihi, G. E and Akpan, I. P 2018. Potentials and challenges of utilizing forage resources for chicken production. Journal of Animal Science and Livestock Production, 2(4): 1- 6.

Ndelekwute, E. K., Okereke, C. O., Assam, E. D. and Effiong, U. O. 2020. Influence of dietary fortification of cassava peel meal with Calapogonium mucunoides on performance of broiler chickens. Nigerian Journal of Animal Production, 47(2): 179 186

Obadina, A. O, Oyewole, O. B., Sanni, L. O. and Abiola, S. S. 2006 Fungal enrichment of cassava peels proteins. African Journal of Biotechnology, 5(3): 302.

Obua, B. E., Okocha, C. N. and Nwaoha, L. E. 2012. Proximate composition and anti-nutritional factors of some forage species used in feeding rabbits in Umudike, humid $\mathrm{S}$ outheastern $\mathrm{Nigeria}$. International Journal of Agriculture and Rural development, 15 (3):1275-1286.

Odunsi, A. A., Onifade, A. A. and Oyewole, S. O.2001. Utilization of cassava peel meals with or without sheabutter fat in diets of egg-type chickens. Indian Journal of Animal Science, 20: 31-36.

Oladunjoye, I. O., Ojebiyi, O. and Amao, O. A. 2010 Effect of feeding processed cassava (manihot esculenta crantz) peel meal based diet on the performance characteristics, egg quality and blood profile of laying chicken. Journal of Agriculture and Rural Development in the Tropics and
Subtropics, 43(2): 119-126.

Olomu, J. M. 1995. Monogastric Animal Nutrition: Principles and Practice. Jachem Pub. Benin, Nigeria. 80 98.

Oluyemi, J.A. and Roberts F.A. 2000. Poultry Production in Warm Wet Climate. $2^{\text {nd }}$ ed. Spectrum Books Ltd. Ibadan, Nigeria.

Oyebimpe, K., Fanimo, A. O., Oduguwa, A. D. and Biobaku, W. O. 2006. Response of broiler chickens to cassava peel and maize offal in cashew nut meal-based diets. Achivos de Zootecnia, 55(211): 302.

Stapleton, J. 2015. Processing African cassava peels, potentially a billion d o 11 a r b u s i n e s s. www.news.ilri.org/2015/11/26/afri can-cassava-peels/. Accessed January 20, 2020.

Scott, M., Hili, N. F, Parson, E. H (Jr.) and Buckner, J. H. 1969. Studies on duck nutrition. 7: Effect of dietary energy protein relationships upon growth, feed utilization and carcass composition in market ducking. Poultry Science, 38: 497 - 507.

Steel, R. G. D. and Torrie, J. H. 1980. Principles and Procedures of Statistics. M c G r a w Hill International Books Co., Sydney.

Ukachukwu, S. N. 1997. Alternative feedstuffs and least cost rations for monogastric animals in Nigeria. Nigerian Journal of Cooperative and Rural Development, 5: 14-17.

UUMS. 2019. University of Uyo Meteorological Station Report, Bulletin 6

Zafar, F., Idrees, M. and Ahmed, Z. 2005. Use of apple by- products in poultry rations in broiler chicks. Pakistan Journal of Physiology, 1: 1-2.

Received: $10^{\text {th }}$ September, 2020 Accepted: $5^{\text {th }}$ January, 2021 